\title{
The Use of Twitter by Politicians During June 2015 and November 2015 General Elections the Case of PDP
}

\author{
Ferihan Polat \\ Assistant Professor, Pamukkale University \\ fyildirim@pau.edu.tr \\ Özlem Özdeşim Subay \\ Phd Candidate, Pamukkale University \\ oikiz@pau.edu.tr
}

\begin{abstract}
Nowadays, one of the mechanisms used by politicians in order to reach mass over is social media with the development of information and communication technologies. In this sense, as a free social media tool, Twitter, is one of the most used social media websites with the features of diffusion of thoughts directly on Internet and easy accessibility. This study evaluates that how and for what purposes Twitter is used by the candidates of Peoples' Democratic Party during the June 2015 and November 2015 General Elections in Turkey. For this aim, Twitter accounts of two co-chairman of PDP Selahattin Demirtaş and Figen Yüksekdağ; Deputy Chairman of Parliamentary Group of PDP Pervin Buldan; Parliament Vice President of Group of PDP İdris Baluken and Administrative Authority of Parliament of PDP Sırrı Süreyya Önder are analyzed during two election times in one month period. As a result of this study, during two election times, differentiation of political language, decrease of peace rhetoric and hardening of opposite language as a parallel of the development of armed conflict in this period are observed in candidates of PDP which claims of being the party of Turkey peoples.
\end{abstract}

Keyword: 2015 June General Elections, 2015 November General Elections, The Political Use Of Twitter, Peoples' Democratic Party.

\section{Use of Twitter by Politicians:}

When it comes to reaching the masses, politicians would like to make use of the faintest opportunity they acquire and the advances in information and communication technologies, especially the social media tools provide them this opportunity. Thus, Twitter, which is a free social media medium that lets users send 140 character long posts to their followers, is a functional communication tool, since it could spread ideas directly in Internet environment and its easy access. Twitter is open for communications continuously and thus, used extensively in social and political events (Enli and Skogerbø, 2013: 763- 764).

Established in 2006, Twitter is the most popular microblog site among other social media tools in the world. The reason for this popularity is the free registration of the users and availability of the capacity to send 140 character short messages called tweets to their followers on any subject. Contrary to other social network sites such as Facebook and My Space, Twitter does not require approval or permission to follow or to be followed by someone. Two significant features that characterize Twitter are the fact that it requires an answer to the question "What's happening?" and the answer is limited to a text of 140 characters long (ikiz et al., 2014: 44).

Twitter is one of the most visited web sites globally and in several countries, and number of users that visit Twitter as a social media tool increases rapidly everyday. As a result of the number of tweets sent during the protests that were 
organized after the elections in Iran in June 2009, and the tweets of American student James Karl Buck, who was jailed during the anti-government demonstrations in Egypt in 2008, Twitter became an important field of study in social sciences (ikiz et al., 2014: 44).

Twitter also became a subject in academic studies, since it is the most popular social media tool among politicians. However, the number of such studies is actually limited, and these studies are concentrated in the United States of America. For example, Gulati and Williams (2010) investigated how the candidates used social media in 2010 elections in the USA. They determined that most of the House of Representatives candidates had Facebook profiles, Twitter and YouTube accounts and argued that Twitter, Facebook and YouTube usage had no affect on the voter profile.

In another study, Williams and Gulati (2010) demonstrated that congressmen utilized Twitter more efficiently and frequently than house representatives. In that study, it was premeditated that local demographics and the age of the candidate was not effective on Twitter use, the source of election and party campaigns, however, was an effective factor. Similarly, Lassen and Brown (2011) studied the reasons why congressmen started to use Twitter, and found that it was due to the membership of the candidate to a smaller party, the fact that party leader forced them to use social media, the young age of the candidate and being a senate member. Furthermore, it was reported that Twitter use did not have any effect on election weakness.

Chi and Yang (2010a) scrutinized the motives behind Twitter use in 111 th House of Representatives based on transparency and electorate reach, and they determined that Republican candidates used Twitter to reach their constituency and to create an agenda, and Democrat candidates mostly used it for transparency. In another study, Chi and Yang (2010b) claimed that Democrat Party candidates used Twitter more than Facebook and Twitter and Facebook were complementary web sites. Golbeck on the other hand, analyzed 6000 tweets to determine how and for which purposes the congress members reached the voters on Twitter. Findings of that study showed that congress members mostly used Twitter to provide information, to share articles about themselves and to announce their daily activities. These findings indicated that Twitter was generally used to advertise and to distinguish one's self, rather than to increase transparency. Twitter was not a tool, which was frequently used by congress members to make direct contact with citizens (Golbeck et al., 2010).

\section{Use of Twitter by Politicians in Turkey:}

There are studies, albeit few, that were conducted to investigate how Twitter was used by political parties and leaders in Turkey. Sancar (2013) conducted the first ever study on the subject and investigated the Twitter accounts of the leaders of political parties that were represented in the parliament in 2012 and then President Abdullah Gül. The study identified that Twitter was used the most by Republican People's Party (RPP) leader Kemal Kılıçdaroğlu, followed by People's Democratic Party (PDP) co-chair Selahattin Demirtaş, however it was not used effectively by then Justice and Development Party (JDP) leader and prime minister Recep Tayyip Eroğan, Nationalist Movement Party (NMP) leader Devlet Bahçeli and President Abddulah Gül, and these individuals used Twitter for one way communications and never interacted with citizens. It was determined that leaders with an interaction potential were Kılıçdaroğlu and Demirtaş.

In another study in the field conducted by Sobacı and Karkın (2013), the content of tweets sent by mayors between January $1^{\text {st }}$ and June $30^{\text {th }}, 2012$ were scrutinized and it was identified that only $10.7 \%$ of these tweets included a direct interaction with citizens. Memiş (2015) investigated the Twitter accounts of 12 mayors to determine their degree and type of social media use with respect to participation in local public policies within the municipality organization and mayor level and found that interaction with citizens were limited in personal social media accounts and remained on the level of providing information, which is considered as the first stage of interaction.

Çetin (2015) investigated the Twitter use of mayor candidates in 2014 local elections and identified that mayors had low level of interaction with citizens, significant portion of the sharing was conducted by their supporters and politicians usually did not develop a discussion culture by opening their accounts to opposition views. In this respect, politicians continued to soliloquize in information and communication tools, transferring their monologue practices in conventional media.

İkiz et al. (2014) scrutinized the twitter use of 16 mayor candidates in 2014 local elections and their findings supported that of Çetin (2015). The study by İkiz et al. (2014) showed that mayor candidates primarily used Twitter to announce their 
location and activity information, and tended to introduce their public service policies and plight, instead of discussing their policies with the electorate.

\section{Political Environment in Turkey between June 2015 and November 2015 General Elections}

Kurdish issue is one of the most significant problems in Turkey that stigmatized the last thirty years. Terrorist actions of PKK from the initial attacks against the state security forces in Eruh and Şemdinli in 1984 to the "resolution process" that filled the agenda towards the end of 2012 caused numerous financial and emotional damages. Terrorist actions that occurred within the 38-year period resulted in $40-50$ thousand deaths, thousands of unidentified murders, depopulation of thousands of villages and smaller settlements, millions of immigrants and financial losses amounting to 1.5 trillion US dollars (Aydın, 2014: 257).

"Resolution process" commenced with the meetings held by National Intelligence Organization (MIT) officers with imprisoned PKK leader Abdullah Öcalan at Imralı prison at the end of 2012, and started to be discussed in public following the announcement by government. A message by Ocalan was conveyed at a crowded activity in Diyarbakır by then Peace and Democracy Party (PDP, now People's Democratic Party) members of parliament and a three-stage plan was announced at Qandil Mountain, where PKK headquarters were located. According to this plan, PKK militants started to withdraw from the country, public officials held hostage by PKK were released and expectations from the government to legislate the judiciary infrastructure for democratization were started to be expressed frequently. On the other hand, the government, to receive feedback from public opinion and to enable a smooth transition into the understanding of the process, introduced a committee of wise men, which was also proposed by Öcalan and main opposition RPP. A Resolution Commission was formed in the parliament, which prepared a "democratization package" and presented it to the public on October 1, 2013 (Aydın, 2014: 228).

Imralı talks were finalized on February 28, 2015 and an agreement was reached for the disarmament of PKK with Öcalan and Qandil. Ten articles that included an extensive democratization package was read at a meeting at Dolmabahçe Palace in Istanbul with the participation of Deputy Prime Minister Yalçın Akdoğan, Interior Minister Efkan Ala, JDP Group Deputy Chairman Mahir Ünal and Sırrı Süreyya Önder, Pervin Buldan and İdris Baluken of the İmralı Committee. National and local dimensions of democratic politics and democratic resolution would be redefined, the concept of national identity would be reformulated and pluralist life would be guaranteed by the constitution through redefinition of the democratic republic, joint homeland and and republic with democratic criteria within the context of Dolmabahçe Agreement (BBC, July 17, 2015). However, despite all promising precepts, Dolmabahçe Agreement failed to move the resolution process forward. Immediately after PDP Co-chair Demirtaş uttered the phrase "We will not let you be the president [of a presidential system]" in his party group meeting on March 17, Erdoğan said he did not consider the agreement positively on March 20. According to a news report published in Cumhuriyet newspaper on September 18, 2015, Dolmabahçe Agreement was shelved due to the lack of PDP support for Erdoğan's presidency and providing incomplete information about the process to Erdoğan (Cumhuriyet, September, 18 2015). After the that statement of PDP Co-Chair Demirtaş in the parliament, clashes between PKK and armed forces erupted in Ağrı on April 11 and 4 soldiers died.

The attempts of PYD in southern Syria to form a government created a possibility of Turkish military intervention, which increased the tensions between the parties even further. The tensions escalated as a result of a live bomb attack organized by a IS terrorist during the presser of Socialist Revolutionary Youth Movement (SDGH) members, which were gathered at Suruç to go to Kobane, and the consequent death of 32 people. As a result KCK (Group of Communities in Kurdistan) CoChair Cemil Bayık called on the people to take arms and to dig trenches and tunnels. On July 24, Turkish Armed Forces (TAF) jets organized airstrikes against IS in Northern Syria and and against PKK in Northern Iraq. This was the first military operation against PKK in three years. As a result, the resolution process was totally forgotten and nationwide operations against PKK recommenced.

October 10, 2015 witnessed the most deadly suicide bomb attack in the history of Turkish Republic in Ankara around 10.04 local time. A peace rally was organized by Revolutionary Workers' Unions Confederation (DISK), Public Workers' Unions Confederation (KESK), Union of Chambers of Turkish Engineers and Architects (TMMOB), PDP and Turkish Medical Association and several other non-governmental organizations on October $10^{\text {th }}$. However, before the rally even started, at the junction where the main railway station was located, while the groups were gathering for the rally, 2 explosions took place 3 seconds apart and 107 people lost their lives and 500 were wounded as a result. 


\section{Twitter Use by PDP Parliamentarians during June 2015 and November 2015 General Elections}

General elections held on June 7, 2015 was repeated three months later on November 1, 2015 since no party was able to form a single party government and the failure of all coalition attempts. Between the two elections, for the first time in Turkish political history an election cabinet ruled the country. However, these four months that the election government ruled the country became the scene of one of the darkest periods in the history of the republic.

In the present study, how and for what purpose Twitter, which was considered within the context of information and communication technologies, was used by Peoples' Democratic Party parliamentarian candidates during campaign periods of June 7 and November 1 general elections were evaluated. The reason why the sample group included PDP candidates was the change in the rate of votes and number of seats they won in the parliament between these two elections. PDP received $13.1 \%$ of the total votes and won 80 seats in the parliament in June 7 general elections, demonstrating a huge success when compared to previous terms. However, the party was not as successful in November 1 general elections, where PDP received $10.8 \%$ of the votes and won only 59 seats.

In the present study, the tweets sent by PDP co-chairs and group deputy chairmen during the one month periods before June 7 (May 7 - June 7) and November 1 (October 1 - November 1) general elections were evaluated. The universe of the study was PDP election candidates, while the sample included the party co-chairs Selahattin Demirtas and Figen Yüksekdağ and group deputy chairman İdris Baluken, parliamentary deputy speaker Pervin Buldan and parliamentary administrator Sırrı Süreyya Önder. The tweets sent by individuals in the sample were assessed based on the categories of democratization, peace, alienation, security, mobilization, and location and activity notification.

Democratization was selected as a category, because most countries in the world claim that they are closely attached to the democratic system. Democracy principle generally includes the elements of the participation of all people in the process of determination of the relationship between the individual and society, establishment of a majority rule, which respects the rights of minorities, protection of individual rights and freedoms, and providing equal opportunities to all members of the society (Çam, 1995: 388- 389). Cooperation of the government with masses in making decisions affecting the public and regulation of the affairs, accountability of the government to citizens in public affairs and equal citizenship rights for all citizens are in the core of democracy (Schmidt, 2000:13).

As a concept, the term "other" denotes the one who is not one of "us" and differentiates individuals and groups from each other. "Us" and the creation of "the other" against the first is a social process. To be able to create a group bias, first a group consciousness should be developed and thus, groups are differentiated and isolated from one another. Group bias is made of the shared bias of members of a particular group about the members of another group and its members. "The other" is generally loaded with negativity. The practical benefit of a society creating "others" is basically a superiority/inferiority relationship. The superior one defined the other as passive, and worthy of every negative attribute. Supervising and dominating one creates the other for instrumental purposes to maintain its control, not only to legitimize its control over the other (Bilici,2011:4). Thus, the phenomenon of alienation is utilized by politicians to create bias in the society in building the ideology in political process. Therefore, it was selected as one of the categories of assessment in the present study.

In the study, tweets that maintained the hope for peace were considered within the peace category due to the differentiation of the political process between the two elections and the sliding of the agenda from the peace process towards security concerns, and tweets that expressed security concerns, criticizing the government were considered within the category of security and the reflections of these social events in politicians' rhetoric were evaluated.

Between May 7 and June 7 PDP parliamentary candidates Selahattin Demirtaş, Figen Yüksekdağ, İdris Baluken, Pervin Buldan and Sırrı Süreyya Önder tweeted a total of 262 times, while they tweeted 204 times between October 1 and November 1. Table 1 demonstrates the tweets sent by these five parliamentary candidates in both periods based on the categories used in content analysis.

Table 1. Tweets sent by PDP parliamentary candidates during the periods of May 7 - June 7 and October 1 and November 1 by category 


\begin{tabular}{|c|c|c|c|c|c|c|c|c|c|c|c|c|}
\hline \multirow{2}{*}{$\begin{array}{l}\text { Categori } \\
\text { es }\end{array}$} & \multicolumn{2}{|c|}{ Democratization } & \multicolumn{2}{|l|}{ Peace } & \multicolumn{2}{|c|}{ Alienation } & \multicolumn{2}{|c|}{ Security } & \multicolumn{2}{|c|}{ Mobilization } & \multicolumn{2}{|c|}{$\begin{array}{l}\text { Location and } \\
\text { Activity } \\
\text { Notification }\end{array}$} \\
\hline & $\begin{array}{l}\text { \# of } \\
\text { tweets }\end{array}$ & $\%$ & $\begin{array}{l}\text { \# of } \\
\text { tweets }\end{array}$ & $\%$ & $\begin{array}{l}\text { \# of } \\
\text { tweets }\end{array}$ & $\%$ & $\begin{array}{l}\text { \# of } \\
\text { tweets }\end{array}$ & $\%$ & $\begin{array}{l}\text { \# of } \\
\text { tweets }\end{array}$ & $\%$ & $\begin{array}{l}\text { \# of } \\
\text { tweets }\end{array}$ & $\%$ \\
\hline $\begin{array}{l}\text { May 7- } \\
\text { June } 7\end{array}$ & 9 & $3,42 \%$ & 19 & $7,22 \%$ & 23 & $8,75 \%$ & 35 & $13,31 \%$ & 42 & $15,97 \%$ & 135 & $\begin{array}{l}51,33 \\
\%\end{array}$ \\
\hline $\begin{array}{l}\text { October } \\
1- \\
\text { Novemb } \\
\text { er } 1\end{array}$ & 0 & $0 \%$ & 3 & $1,47 \%$ & 57 & $27,96 \%$ & 52 & $25,49 \%$ & 16 & $7,84 \%$ & 76 & $\begin{array}{l}37,25 \\
\%\end{array}$ \\
\hline
\end{tabular}

An analysis of the tweets sent in both election periods based on democratization, peace, alienation, security, mobilization and location and activity notification would show a differentiation parallel to the terror and violence events experienced nationwide. In May 7 - June 7 period the rate of tweets on security was $13.31 \%$, on alienation was $8.75 \%$ and those focused on the longing for peace were $7.22 \%$. During this period when resolution process was still in close memory, it was observed that the tweets of the researched five parliamentarian candidates concentrated in the areas of democratization, peace, mobilization and location and activity notification, while during the October 1 - November 1 period they mostly tweeted on alienation, security and location and activity notification.

It was found that PDP parliamentary candidates utilized Twitter mostly (37.25\%) for location and activity notifications between October 1 and November 1. However, the same ratio was $51.33 \%$ for May 7 - June 7 period, it fell to $37.25 \%$ during the second elections. It was followed by alienation with $27.96 \%$, and it could be stated that political rhetoric became harsher, and criticism of the government increased since the same rate was only $8.75 \%$ before June 7 elections. Furthermore, security concerns and government criticism was determined as $25.49 \%$ before November 1 and since the same rate was $13.31 \%$ before June 7 , it was obvious that in the second elections the terrorist events influenced the political rhetoric. In addition, the rate of the tweets on peace decreased from $7.22 \%$ before June 7 to $1.47 \%$ during the second election campaign period. In this period, no tweets within the context of democratization in Turkey were sent by PDP parliamentary candidates that were the subjects of the present study. In this period, when the resolution process was "shelved," as a result of the political climate in the country, it was observed that PDP parliamentary candidates turned away from the democratization and peace rhetoric. The environment of concern created by the violent events of this period caused hardening of the political language of PDP parliamentary candidates as well.

Table 2. Content of Tweets Sent by PDP Parliamentary Candidates Between May 7 and June 7

\begin{tabular}{|c|c|c|c|c|c|c|c|c|c|c|c|c|}
\hline \multirow{2}{*}{$\begin{array}{l}\text { Categories } \\
\text { PDP Candidates }\end{array}$} & \multicolumn{2}{|c|}{ Democratization } & \multicolumn{2}{|l|}{ Peace } & \multicolumn{2}{|c|}{ Alienation } & \multicolumn{2}{|c|}{ Security } & \multicolumn{2}{|c|}{ Mobilization } & \multicolumn{2}{|c|}{$\begin{array}{l}\text { Location and Activity } \\
\text { Notification }\end{array}$} \\
\hline & $\begin{array}{l}\# \text { of } \\
\text { tweets }\end{array}$ & $\%$ & $\begin{array}{l}\# \text { of } \\
\text { tweets }\end{array}$ & $\%$ & $\begin{array}{l}\# \text { of } \\
\text { tweets }\end{array}$ & $\%$ & $\begin{array}{l}\text { \# of } \\
\text { tweets }\end{array}$ & $\%$ & $\begin{array}{l}\text { \# of } \\
\text { tweets }\end{array}$ & $\%$ & $\begin{array}{l}\# \text { of } \\
\text { tweets }\end{array}$ & $\%$ \\
\hline Selahattin Demirtaş & 0 & $0 \%$ & 1 & $8,33 \%$ & 2 & $16,67 \%$ & 3 & $25 \%$ & 3 & $25 \%$ & 3 & $25 \%$ \\
\hline Figen Yüksekdağ & 2 & $15,38 \%$ & 0 & $0 \%$ & 0 & $0 \%$ & 0 & $0 \%$ & 9 & $69,23 \%$ & 2 & $15,38 \%$ \\
\hline İdris Baluken & 0 & $0 \%$ & 6 & $9,52 \%$ & 15 & $23,81 \%$ & 10 & $15,87 \%$ & 4 & $6,35 \%$ & 28 & $44,44 \%$ \\
\hline Pervin Buldan & 7 & $4,55 \%$ & 10 & $6,49 \%$ & 5 & $3,25 \%$ & 19 & $12,34 \%$ & 17 & $11,04 \%$ & 96 & $62,34 \%$ \\
\hline $\begin{array}{l}\text { Sı̈rı Süreyya } \\
\text { Önder }\end{array}$ & 0 & $0 \%$ & 2 & $9,52 \%$ & 1 & $4,76 \%$ & 3 & $14,29 \%$ & 9 & $42,86 \%$ & 6 & $28,57 \%$ \\
\hline Total & 9 & $3,42 \%$ & 19 & $7,22 \%$ & 23 & $8,75 \%$ & 35 & $13,31 \%$ & 42 & $15,97 \%$ & 135 & $51,33 \%$ \\
\hline
\end{tabular}

Content of the tweets that five scrutinized parliamentary candidates in the present study sent between May 7 and June 7 are presented in Table 2. Accordingly, Selahattin Demirtaş tweeted 12 times and used Twitter $25 \%$ for mobilization, security and location and activity notification. In the same period, Figen Yüksekdağ utilized Twitter $69.23 \%$ for mobilization, followed by $15.38 \%$ democratization and location and activity notification. Two female politicians, Figen Yüksekdağ and Pervin Buldan tweeted about democratization, stressing women's rights. Baluken used Twitter mostly for location and activity notification (44.44\%), followed by $23.81 \%$ for alienation. As could be observed in the previously mentioned tweet samples, Idris Baluken expressed the harshest criticism against the government. Proportionally, Baluken and Demirtaş were the 
politicians within the context of the present research that used alienation rhetoric against the government the most. Pervin Buldan was the politician who used Twitter for location and activity notification the most $(62.34 \%)$. It was followed by tweets on criticisms expressed within the context of security, voicing her concerns about Saturday Mothers. Buldan was the politician who stressed peace the most with 10 tweets. Sırrı Süreyya Önder tweeted mostly on mobilization on Twitter (42.86\%), followed by location and activity notification with $28.57 \%$. Finally, findings of the present study demonstrated that Twitter was used by the politicians under scrutiny between May 7 and June 7 for location and activity notification the most with a rate of $51.33 \%$, followed by mobilization with $15.97 \%$.

Table 3. 1 Content of Tweets Sent by PDP Parliamentary Candidates Between October 1 and November 1

\begin{tabular}{|c|c|c|c|c|c|c|c|c|c|c|c|c|}
\hline Categories & Democr & ization & Peace & & Alienatic & & Security & & Mobiliz & & $\begin{array}{l}\text { Locatior } \\
\text { Activity } \\
\text { Notifica }\end{array}$ & \\
\hline $\begin{array}{l}\text { PDP } \\
\text { Candidates }\end{array}$ & $\begin{array}{l}\text { of } \\
\text { tweets }\end{array}$ & $\%$ & $\begin{array}{l}\# \text { of } \\
\text { tweets }\end{array}$ & $\%$ & $\begin{array}{l}\# \text { of } \\
\text { tweets }\end{array}$ & $\%$ & $\begin{array}{l}\# \text { of } \\
\text { tweets }\end{array}$ & $\%$ & $\begin{array}{l}\# \text { of } \\
\text { tweets }\end{array}$ & $\%$ & $\begin{array}{l}\text { of } \\
\text { tweets }\end{array}$ & $\%$ \\
\hline $\begin{array}{l}\text { Selahattin } \\
\text { Demirtaş }\end{array}$ & 0 & $0 \%$ & 1 & $6,67 \%$ & 3 & $20 \%$ & 3 & $20 \%$ & 7 & $46,67 \%$ & 1 & $6,67 \%$ \\
\hline $\begin{array}{l}\text { Figen } \\
\text { Yüksekdağ }\end{array}$ & 0 & $0 \%$ & 0 & $0 \%$ & 3 & $27,27 \%$ & 5 & $45,45 \%$ & 3 & $27,27 \%$ & 0 & $0 \%$ \\
\hline $\begin{array}{l}\text { İdris } \\
\text { Baluken }\end{array}$ & 0 & $0 \%$ & 1 & 0,99\% & 45 & $44,55 \%$ & 23 & $22,77 \%$ & 4 & $3,96 \%$ & 28 & $27,72 \%$ \\
\hline $\begin{array}{l}\text { Pervin } \\
\text { Buldan }\end{array}$ & 0 & $0 \%$ & 1 & $1,3 \%$ & 6 & $7,79 \%$ & 21 & $27,27 \%$ & 2 & $2,6 \%$ & 47 & $61,04 \%$ \\
\hline Total & 0 & $0 \%$ & 3 & $1,47 \%$ & 57 & $27,96 \%$ & 52 & $25,49 \%$ & 16 & $7,84 \%$ & 76 & $37,25 \%$ \\
\hline
\end{tabular}

Content of the tweets sent by PDP parliamentary candidates Selahattin Demirtaş, Figen Yüksekdağ, İdris Baluken and Pervin Buldan between October 1 and November 1 are presented in Table 3. Twitter account of PDP parliamentary candidate Sırrı Süreyya Önder, whose tweets were included in the analysis for May 7 - June 7 period, was hacked in August and Önder was not able to use his account after August. Thus, Sırrı Süreyya Önder's Twitter account was excluded from analysis for October 1 - November 1 period.

Classification of the contents of the tweets sent by scrutinized individuals in the present study is displayed in Table 3. Based on this data, Selahattin Demistaş prefferred to send tweets mostly to activate mobilization (46.67\%), followed by alienating rhetoric with $20 \%$ and criticism on security. Figen Yüksekdağ mostly voiced her concerns and criticisms on security in her tweets (45.45\%). It could be stated that Yüksekdağ was affected by the process since she never tweeted on that subject back in May 7 - June 7 period. Furthermore, $27.27 \%$ of Yüksekdağ's tweets included alienating rhetoric, and it was observed that Yüksekdağ's language became harsher and increased her criticism against the government. Baluken used Twitter in an alienating manner the most during this period (44.55\%), and this type of content in his tweets increased twice from $23.81 \%$ during the previous elections. Based on the findings of the present study, Baluken was the parliamentary PDP candidate who used alienating rhetoric the most. Peace emphasis in Baluken's tweets, which was $9.52 \%$ in the period before June 7 elections, decreased to $0.99 \%$ in the period before the second elections. An analysis of Pervin Buldan's tweets demonstrated that she used Twitter mostly for location and activity notifications with $61.04 \%$ in this period, similar to the previous period. This was followed by criticisms on security with $27.27 \%$. However, with a rate of $7.79 \%$, Buldan had the least alienating rhetoric among the investigated candidates. Between October 1 and November 1, 4 investigated politicians tweeted a total of 204 times with an average of 51 tweets per candidate.

\section{RESULT}

As industrial society evolved into information society, information and communication technologies transformed social and political communications, diversifying the mechanisms available for the politicians to reach citizens. Research showed that social media is extensively used by the politicians, especially during elections. One of the social media tools, Twitter is lately increasing its effectiveness in political communications. Defined as verbal or written use of language as a form of social practice discourse is considered as one of the significant tools that convey ideologies (Evre, 2009: 135). Thus, the present study investigated the reflections of social events into the discourse of PDP politicians during two election periods. 
Results of the present study demonstrated that PDP politicians frequently used Twitter during both election periods, led by Pervin Buldan and Idris Baluken. The tensions in political process and terror events caused radicalization and sharpening of political rhetoric in Turkey. In the period between May 7 and June 7, PDP politicians used Twitter for location and activity notification with a rate of $51.33 \%$, followed by mobilization with $15.97 \%$. In this period $13.31 \%$ of the tweets were about security, $8.75 \%$ of the tweets included alienation, and $7.22 \%$ of the tweets voiced the longing for peace.

However, between October 1 and November 1, discourse of the politicians changed along with the social events. It was found that PDP parliamentary candidates mostly utilized Twitter for location and activity notification (37.25\%). However, while this rate was $51.33 \%$ before June 7 , it decreased to $37.25 \%$ before November 1 elections. This was followed by alienation with $27.96 \%$, and when it is considered that the same rate was $8.75 \%$ before June 7 elections, it could be argued that political discourse harshened and the dose of the criticism against government increased before November 1 elections. Furthermore, concerns for security and related criticisms of the government were voiced in $25.49 \%$ of the tweets, and since the same rate was $13.31 \%$ in the period before June 7 elections, it could be deducted that experienced terror events in that period influenced the political discourse. In addition, peace, which was the subject matter of $7.22 \%$ of the tweets before June 7 , decreased to $1.47 \%$ during the second elections. In the time period covered by the scope of the present study, tweets of the PDP parliamentary candidates did not include a discourse on democratization of Turkey.

Results of the current study demonstrate that interruption of the peace process in Turkey, the increase in terrorist events and the tensions in political cycles increased the alienating discourse in the language used by PDP parliamentary candidates, similar to the nation at large. As a result of the present study, it could be argued that the decrease in PDP votes between the elections of June 7 and November 1 demonstrated the hypothesis that the new political process and discourse was not beneficial politically for PDP. Although Peoples' Democratic Party was established on June 22, 2014 with the premise of a party for the whole Turkey, it is still a question mark whether the party has accomplished this premise especially before November 1 elections. Because a party for Turkey should respond to the demands of all citizens, not only those who live in Eastern or Southeastern regions. In fact, PDP that defines the party as the representative of "all oppressed and exploited, all alienated and ignored peoples and belief groups, women, workers, laborers, the youth and unemployed" in the party covenant returned to the image of the old Peace and Democracy Party, which defended the rights of Kurdish ethnic identity, during these two election periods.

\section{References:}

Aydın, N. (2014). "Türkiye'de Kürt Sorununu Çözüm Sürecinde Algının Yeniden Inşası", Gazi Üniversitesi Sosyal Bilimler Enstitüsü, Doktora Tezi.

BBC (2015), “Erdoğan: 'Dolmabahçe mutabakatı' ifadesini cımbızlarım”, 17 Temmuz 2015, erişim adresi: http://www.bbc.com/turkce/haberler/2015/07/150717_erdogan_hdp, erişim tarihi: 21.12.2015.

Bilici, İ. E. (2011). Oryantalist Seyahatnamelerde Türk Imgesi Üzerine Bir İnceleme, Gümüşhane Üniversitesi Iletişim Fakültesi Elektronik Dergisi Sayı:2, ss 1-21.

Chi, F. ve Yang, N. (2010a). Twitter in Congress: Outreach vs Transparency. MPRA Paper No. 24060.

Chi, F. ve Yang, N. (2010b). Twitter Adoption in Congress: Who Tweets First?, MPRA Paper No. 23225,

Cumhuriyet (2015), "Erdoğan'ı aldattılar", 18, Eylül, 2015, erişim adresi: http://www.cumhuriyetarsivi.com/katalog/192/sayfa/2015/9/18/4.xhtml, erişim tarihi: 20.12.2015.

Çam, E. (1995). Siyaset Bilimine Giriş, 4. Basım, Der Yayınları, İstanbul.

Çetin, S. (2015), "2014 Yerel Seçimlerinde Büyükşehir Belediye Başkan Adaylarının Twitter Kullanımları Üzerine Karşılaştırmalı Analiz", Global Medya Journal TR Edition, 5/10, 87-119.

Enli, G.S., Skogerbø, E. (2013). "Personalized Campaigns in Party-Centred Politics: Twitter and Facebook as Arenas for Political Communication", Information Communication and Society. 16/ 5, 757-774. 
İkiz, Ö., Sobacı, M. Z., Yavuz, N., Karkın, N. (2014). "Political Use of Twitter: The Case of Metropolitan Mayor Candidates in 2014 Local Elections in Turkey", (Edt: E. Estevez, M. Janssen, ve L. Soares Barbosa), ICEGOV '14: Proceedings of the 8th International Conference on Theory and Practice of Electronic Governance, 41-50, New York, NY.

Lassen, D. S. ve Brown, A. R. (2011). "Twitter: The Electoral Connection?", Social Science Computer Review. 29, 4, 419436.

Memiş, L. (2015). "Social Networks as a New Tool of E-participation in Local: Example of Facebook and Twitter / Yerel Ekatııımın Yeni Aracı Olarak Sosyal Ağlar: Facebook ve Twitter Örnekleri", Çankırı Karatekin Üniversitesi İktisadi ve Idari Bilimler Üniversitesi, 5/1.

Sancar, G. A. (2013). "Public Relations 2.0 and The Use of Twitter of Political Leaders in Turkey", Online Journal of Communication and Media Technologies", 3/1, Ocak, 181-194.

Schmidt, M. G. (2001). Demokrasi Kuramlarına Giriş, (çev: M. Emin Köktaş), Vadi Yayınları, Ankara.

Sobacı, Z. ve Karkın, N. (2014). "The Use of Twitter by Mayors in Turkey: Tweets for Better Public Services?", Government Information Quarterly, 30, 417-425, Elsevier.

Williams, C. B. ve Gulati, G. J. J. (2010). Communicating with Constituents in 140 Characters or Less: Twitter and the Diffusion of Technology Innovation in the United States Congress. Working Papers. Paper 43. 